\title{
ANALISIS FAKTOR-FAKTOR YANG MEMPENGARUHI PENERIMAAN PAJAK KENDARAAN BERMOTOR DI PROVINSI KALIMANTAN SELATAN
}

\author{
Dwi Ajeng Kartini Apriliyanti ${ }^{1}$ \\ Harianto ${ }^{1}$ \\ Dedi Budiman Hakim ${ }^{1}$
}

\author{
${ }^{1}$ Institut Pertanian Bogor, Jawa Barat, Indonesia \\ email: dwiajengkartini@gmail.com
}

\begin{abstract}
ABSTRAK
Desentralisasi merupakan penyerahan kekuasaan pemerintahan oleh pemerintah pusat kepada daerah otonom berdasar asas otonomi yang secara umum hasil analisis menunjukkan bahwa desentralisasi telah berdampak positif terhadap pertumbuhan ekonomi di daerah. Terjadinya krisis perekonomian global, mengakibatkan terjadinya perlambatan pertumbuhan ekonomi nasional dan Kalsel dimana perlambatan ini terjadi sejak tahun 2012 dan terus berlanjut sampai dengan tahun 2015 yang kemudian hanya tumbuh sebesar 3,84\%. Realisasi pajak kendaraan bermotor pada tahun 2015-2019 masih berfluktuasi, sehingga perlu diketahui faktor-faktor yang mempengaruhi penerimaan pajak kendaraan bermotor tersebut. Tujuan penelitian ini adalah menganalisis faktor-faktor yang mempengaruhi penerimaan pajak kendaraan bermotor di Provinsi Kalimantan Selatan. Penelitian ini menggunakan jenis data primer dan data sekunder. Metode analisis yang digunakan dalam penelitian ini adalah analisis regresi data panel. Hasil penelitian ini menunjukkan bahwa jumlah kendaraan memiliki pengaruh positif dan signifikan sedangkan jumlah penduduk, PDRB perkapita, inflasi dan sistem pajak tidak berpengaruh signifikan terhadap penerimaan pajak kendaraan bermotor di Provinsi Kalimantan Selatan.
\end{abstract}

Kata Kunci :Analisis Regresi Data Panel, Pajak Kendaraan Bermotor.

\begin{abstract}
Decentralization is the transfer of governmental power by the central government to autonomous regions based on the principle of autonomy. In general, the results of the analysis show that decentralization has had a positive impact on local economic growth. Global economy crisis has affect national economic growth and South Kalimantan slowdown that occurred since 2012 and continued until 2015 which only grew by 3,84\%. The realization of motor vehicle tax in 2015-2019 is still fluctuating even though in certain years it has reached the target, so it is necessary to know the factors that affect the motor vehicle tax revenue. The purpose of this study was to analyze the factors that influenced motor vehicle tax revenue in South Kalimantan Province. The types of data used in this study are primary and secondary data. The analysis method used in this research is panel data regression analysis. The results of this study showed the number of vehicles has a positive and significant effect while population, PDRB per capita, inflation, tax system haven't significant effect on motor vehicle tax revenues in South Kalimantan Province.

Keywords: Panel Data Regression Analysis, motor vehicle tax.
\end{abstract}




\section{PENDAHULUAN}

Desentralisasi merupakan penyerahan kekuasaan pemerintahan oleh pemerintah pusat kepada daerah otonom berdasar asas otonomi. Hal ini sesuai dengan Undang-undang Nomor 23 Tahun 2014. Desentralisasi menyebabkan munculnya otonomi bagi suatu pemerintahan daerah. Pelaksanaan otonomi atau kebijakan desentralisasi selama ini dianggap berpengaruh terhadap pertumbuhan ekonomi daerah. Secara umum hasil analisis menunjukkan bahwa desentralisasi telah berdampak positif terhadap pertumbuhan ekonomi di daerah (Kusuma, 2016). Secara rata-rata tingkat kemandirian provinsi di Indonesia pada tahun 2016-2018 dikategorikan sedang yaitu sebesar 57,43\%, namun dengan terjadinya krisis perekonomian global, mengakibatkan terjadinya perlambatan pertumbuhan ekonomi nasional dan Kalsel dimana perlambatan ini terjadi sejak tahun 2012 dan terus berlanjut sampai dengan tahun 2015 yang kemudian hanya tumbuh sebesar $3,84 \%$ atau berada di bawah angka nasional yang mencapai $4,79 \%$ dengan posisi menurun menjadi ke-27 secara nasional.

Perlambatan perekonomian Kalimantan Selatan telah berdampak terhadap penurunan pendapatan daerah, untuk itu isu tentang peningkatan kapasitas fiskal merupakan salah satu pekerjaan pentingbagipemerintah provinsi, agar pembangunan daerah tetap dapat berlanjut sebagaimana yang diharapkan. Secara umum Pemerintah Provinsi Kalimantan Selatan, kedepannya perlu lebih meningkatkan kinerjanya lagi, agar pemerintah provinsi ini lebih akuntabel, transparan dan profesional, yang pada akhirnya akan berdampak terhadap peningkatan pencapaian indikator-indikator pembangunan daerah (Badan Perencanaan dan Pembangunan Daerah, 2019). Hal ini menjadi isu strategis Pemerintah Daerah Provinsi Kalimantan Selatan yang harus segera ditindaklanjuti dalam rangka percepatan pencapaian visi dan misi pembangunan daerah. Daerah yang berhasil meningkatkan PAD nya secara nyata, mengindikasikan bahwa daerah tersebut telah dapat memanfaatkan potensi yang ada secara optimal (Badan Pusat Statistik, 2019). Dalam hal ini, pemerintah daerah berhak memungut pajak dan retribusi daerah dalam rangka meningkatkan PAD dan pemberian pelayanan kepada masyarakat secara optimal. Realisasi pajak daerah yang telah dipungut oleh Pemerintah Provinsi Kalimantan Selatan sejak tahun 2015-2019 dapat dilihat pada tabel 1.

Tabel 1.

Realisasi Pajak Daerah Provinsi Kalimantan Selatan 2015-2019 (dalam \%)

\begin{tabular}{lccccc}
\hline \multicolumn{1}{c}{ Sumber Pajak Daerah } & $\mathbf{2 0 1 5}$ & $\mathbf{2 0 1 6}$ & $\mathbf{2 0 1 7}$ & $\mathbf{2 0 1 8}$ & $\mathbf{2 0 1 9}$ \\
\hline Pajak Kendaraan Bermotor & 99,35 & 103,33 & 84,63 & 103,86 & 101,34 \\
Bea Balik Nama Kendaraan & 85,04 & 96,82 & 73,79 & 94,23 & 96,57 \\
$\begin{array}{l}\text { Bermotor } \\
\text { Pajak Bahan Bakar Kendaraan }\end{array}$ & 77,68 & 94,61 & 83,21 & 102,48 & 91,59 \\
$\begin{array}{l}\text { Bermotor } \\
\text { Pajak Air Permukaan }\end{array}$ & 96,81 & 95,97 & 88,74 & 103,42 & 102,67 \\
Pajak Rokok & 107,35 & 100,44 & 97,32 & 87,84 & 72,81 \\
\hline
\end{tabular}

Sumber :Badan Keuangan Daerah Prov. Kalsel (2020) 
Persentase realisasi pajak kendaraan bermotor di Provinsi Kalimantan Selatan pada tahun 2015-2019 terlihat masih berfluktuasi dari tahun ke tahun. Tabel 1. menunjukkan kontribusi pajak kendaraan bermotor terhadap pajak daerah dalam kurun waktu 5 (lima) tahun terakhir rata-rata mengalami peningkatan, hanya pada tahun 2017 dan 2019 mengalami penurunan. Hal ini diduga disebabkan masih kurangnya penggalian terhadap potensi pajak kendaraan bermotor yang ada. Target dan realisasi pajak kendaraan bermotor di Provinsi Kalimantan Selatan pada tahun 2015-2019 dapat dilihat pada tabel 2.

Tabel 2.

Target dan Realisasi PKB Provinsi Kalimantan Selatan Tahun 2015-2019

\begin{tabular}{cccc}
\hline Tahun & Target (Rp) & Realisasi (Rp) & Persentase (\%) \\
\hline 2015 & 559.475 .642 .050 & $555.866 .696 .606,00$ & 99,35 \\
2016 & 568.074 .872 .000 & $587.010 .910 .753,00$ & 103,33 \\
2017 & 748.964 .546 .211 & $633.822 .231 .872,00$ & 84,63 \\
2018 & 655.780 .535 .000 & $681.092 .354 .195,40$ & 103,86 \\
2019 & 721.352 .000 .000 & $730.998 .168 .259,00$ & 101,34 \\
\hline
\end{tabular}

Sumber : Badan Keuangan Daerah Prov. Kalsel (2020)

Asumsi kebijakan perencanaan pendapatan daerah pada Rencana Kerja Pemerintah Daerah (RKPD) Tahun Anggaran 2020 diantaranya adalah melalui optimalisasi pendapatan dari pajak kendaraan bermotor dengan cara menerapkan pajak progresif berkeadilan dan mendorong pertumbuhan ekonomi. Asumsi ini didukung oleh kontribusi salah satu pajak daerah yang berpotensi besar seiring dengan adanya pertambahan jumlah penduduk dan daya beli masyarakat yaitu pajak kendaraan bermotor.Penerapan sistem online sebagai katalisator penerimaan pajak kendaraan bermotor dan faktor-faktor lain yang dianggap dapat berpengaruh terhadap penerimaan pajak kendaraan bermotor perlu dievaluasi guna mengetahui sejauhmana pengaruh penerapan kebijakan sistem online dan faktor-faktor lain terhadap kinerja penerimaan pajak kendaraan bermotor di Provinsi Kalimantan Selatan. Kinerja pajak kendaraan bermotor termasuk diantaranya pertumbuhan, kontribusi dan efektifitas sebelum dan sesudah diterapkannya sistem online perlu menjadi perhatian. Perbandingan antara jumlah kendaraan bermotor yang terdaftar sebagai objek pajak dengan realisasi juga menjadi catatan pertimbangan bagi pemerintah daerah dalam menganalisis pertumbuhan pajak kendaraan bermotor. Pencapaian kinerja pajak kendaraan bermotor yang ada di Kalimantan Selatan dapat dijadikan sebagai bahan masukan bagi pemerintah daerah dalam menentukan target yang harus dicapai pada tahun-tahun berikutnya guna mendukung keberhasilan kebijakan pembangunan, namun keberhasilan kebijakan pembangunan daerah tentu saja juga dapat dipengaruhi oleh beberapa faktor baik secara langsung maupun tidak langsung, tidak terkecuali dalam kebijakan perpajakan sektor kendaraan bermotor.

Penelitian yang dilakukan penulis saat ini mengacu pada teori perpajakan dan penelitian terdahulu dengan menambahkan variabel lain berupa jumlah kendaraan sehingga variabel yang akan digunakan untuk melakukan analisis pada penelitian ini adalah jumlah penduduk, jumlah kendaraan, PDRB perkapita, inflasi 
dan sistem pajak. Variabel bebas yang terdiri dari jumlah dan mutasi kendaraan secara bersama-sama berpengaruh positif signifikan terhadap penerimaan pajak kendaraan bermotor di Kota Yogyakarta(Saputra, 2018)menunjukkan bahwa dari hasil penelitian ini juga perlu dilakukan penelitian lebih lanjut guna mengetahui faktor-faktor apa saja yang berpengaruh terhadap penerimaan pajak kendaraan bermotor. Penelitian ini bertujuan untuk menganalisis faktor-faktor yang mempengaruhi penerimaan pajak kendaraan bermotor di Provinsi Kalimantan Selatan tahun 2015-2019.

\section{METODE PENELITIAN}

Objek penelitian ini adalah pajak kendaraan bermotor. Waktu yang digunakan dalam pengambilan dan pengolahan data adalah selama 3 bulan yaitu bulan Oktober sampai dengan Desember 2020. Lokasi penelitian adalah di Badan Keuangan Daerah Provinsi Kalimantan Selatan.Metode yang digunakan adalah analisis regresi data panel. Jenis data yang digunakan pada penelitian ini adalah data primer dan data sekunder. Data primer diperoleh dari hasil wawancara terhadap 5 (lima) orang informan dengan teknik purposive sampling yaitu para ahli/expert yang menguasai tentang pajak kendaraan bermotor pada Badan Keuangan Daerah. Data sekunder diperoleh dari dokumen dan laporan dari Badan Keuangan Daerah terhadap realisasi penerimaan pajak kendaraan bermotor Kalimantan Selatan di 13 kabupaten/kota di Provinsi Kalimantan Selatan maupun dokumen lain dari instansi terkait seperti Badan Perencanaan Pembangungan Daerah, Badan Pusat Statistik, peraturan perundang-undangan, review literature, hasil kajian sejenis dan informasi lainnya yang terkait dengan topik penelitian.

Penelitian yang akan dilakukan oleh penulis akan mengacu pada teori perpajakan menurut (Musgrave, 1989) dan penelitian terdahulu yang dilakukan oleh Saputra dengan menambahkan variabel PDRB perkapita dan dummy berupa sistem onlineterhadap penerimaan pajak kendaraan bermotor. Sehingga teknik analisis yang akan digunakan pada penelitian ini adalah analisis regresi data panel. Data panel adalah tipe data yang terdiri dari variabel-variabel yang dikumpulkan menurut urutan waktu dalam suatu rentang waktu tertentu pada sejumlah individu. Data panel dapat dikatakan sebagai kombinasi dari data kali-silang (cross-section) dan data runtun waktu (timeseries) (Gujarati, 2003).

Terdapat tiga pemodelan yang sering digunakan dalam data panel (Gujarati, 2003) yaitu,

Model Common Effect (CE)

Model common effectadalah model yang memiliki koefisien yang sama untuk setiap unit individu dan periode waktu. Model common effect merupakan model paling sederhana, sering disebut pula sebagai model homogen atau pooled. Model common effect dimodelkan sebagai berikut,

$y_{i, t}=\lambda+x_{i, t} \beta+\varepsilon_{i, t}$

dengan $\lambda_{i}=\lambda$ tidak berkorelasi dengan $x_{i, t}$. 
Estimasi parameter model common effect menggunakan OLS (Ordinary Least Square) dengan menggabungkan data kali-silang dan data runtun waktu tanpa melihat adanya perbedaan unit individu dan periode waktu.

Model Fixed Effect (FE)

Modelfixed effect adalah model yang memiliki konstanta yang tetap untuk setiap unit individu. Perbedaan dari model common effect adalah adanya efek yang tidak teramati (unobservable effect). Model fixed effect dimodelkan sebagai berikut,

$y_{i, t}=\lambda_{i}+x_{i, t} \beta+\varepsilon_{i, t}$

dengan $\lambda_{i}$ bersifat tetap untuk setiap individu, tidak bergantung pada periode waktu, dan berkorelasi dengan $x_{i, t}$.

Estimasi parameter model fixed effect menggunakan LSDV (Least Square Dummy Variables) dengan menambahkan dummy variabel yang bersesuaian dengan masing-masing nilai variabel-variabel independen.

Model Random Effect (RE)

Modelrandom effect adalah model yang memiliki konstanta yang acak dalam hal ini masuk ke dalam komponen error. Perbedaan dari model fixed effect adalah adanya asumsi bahwa $\alpha_{i}$ tidak berkorelasi terhadap variabel independen. Model random effect dimodelkan sebagai berikut,

$y_{i, t}=x_{i, t} \beta+\varepsilon_{i, t}$

$\varepsilon_{i, t}=\lambda_{i}+v_{i, t}$

dengan $\lambda_{i}$ bersifat acak dan tidak berkorelasi dengan $x_{i, t}$, serta $v_{i, t}$ komponen galat khusus, diasumsikan memiliki ekspektasi rata-rata nol dan variansi homogen dalam waktu (homoskedastisitas) serta independen terhadap $x_{i, t}$.

Estimasi parameter model random effect menggunakan GLS (Generalized Least Square).

Analisis data panel meliputi beberapa proses dasar yang harus dilakukan, yaitu uji spesifikasi model, uji signifikansi model, dan uji diagnostik model serta pemilihan model terbaik apabila diperlukan. Model yang digunakan dalam analisis data panel biasanya adalah model FE atau model RE, sedangkan model CE pada dasarnya hanya analisis regresi linier sederhana, sehingga tidak dapat menangkap efek individu atau efek waktu yang terdapat dalam data.

Uji spesifikasi model bertujuan untuk memperoleh model yang cocok atau dapat merepresentasikan data dengan baik. Pengujian yang digunakan adalah uji Hausmann dilanjutkan uji Breusch-Pagan.

Uji Chow membandingkan konsistensi antara model FE dan model CE atau membandingkan model yang lebih cocok terhadap data. Hipotesis awal adalah model commoneffect konsisten dan hipotesis alternatif adalah model fixedeffect konsisten.

Uji Hausmann membandingkan konsistensi antara model FE dan model RE atau membandingkan model yang lebih cocok terhadap data. Dalam perhitungan statistik uji Hausmann diperlukan asumsi bahwa banyaknya kategori kali silang lebih dari jumlah variabel independen (termasuk konstanta) dalam model. Lebih lanjut, diperlukan estimasi variansi kali silang yang positif (tidak selalu dapat dipenuhi oleh model). Apabila kondisi-kondisi tersebut tidak terpenuhi, hanya 
model FE yang dapat digunakan. Hipotesis awal adalah model fixed effect konsisten dan hipotesis alternatif adalah model random effect konsisten.

Uji Breusch-Pagan bertujuan untuk mengetahui ada tidaknya efek individu dan/atau efek waktu dari model yang dibentuk berdasarkan uji Hausmann. Terdapat 3 hipotesis yang digunakan dengan masing-masing statistik uji adalah Lagrange Multiplier berdasarkan uji Chi-Square sebagai berikut, Hipotesis efek individu dengan hipotesis awal tidak terdapat efek individu $(\lambda=0)$ dan hipotesis alternatif adalah terdapat efek individu $(\lambda \neq 0)$, Hipotesis efek waktu dengan hipotesis awal tidak terdapat efek waktu $(\gamma=0)$ dan hipotesis alternatif adalah terdapat efek waktu $(\gamma \neq 0)$, Hipotesis efek individu dan efek waktu dengan hipotesis awal tidak terdapat efek individu dan efek waktu $(\lambda=0 ; \gamma=0)$ dan hipotesis alternatif adalah terdapat efek individu dan efek waktu $(\lambda \neq 0 ; \gamma=0)$

Uji signifikansi model bertujuan untuk melihat signifikan tidaknya model secara simultan dan koefisien pada model secara parsial.

Pada uji signifikansi model dilakukan pengujian semua koefisien variabel independen yang terdapat pada model secara simultan atau bersama-sama. Hipotesis awal adalah semua koefisien pada model tidak signifikan $\left(\beta_{1}=\beta_{2}=\right.$ $\cdots=\beta_{p-1}=0$ ) atau dapat diartikan sebagai model tanpa variabel independen (model dengan intersep saja) dapat merepresentasikan data. Sedangkan hipotesis alternatif adalah tidak semua koefisien pada model tidak signifikan $\left(\exists \beta_{p} \neq 0\right)$ atau dapat diartikan sebagai model dengan variabel independen lebih baik daripada model tanpa variabel independen.

Pada uji signifikansi koefisien model dilakukan pengujian koefisien variabel independen yang terdapat pada model secara parsial atau terpisah-pisah. Hipotesis awal adalah koefisien pada model tidak signifikan $\left(\beta_{p}=0\right)$. Sedangkan hipotesis alternatif adalah koefisien pada model signifikan $\left(\beta_{p} \neq 0\right)$.

Uji diagnostik model adalah pengujian terhadap model dengan beberapa asumsi klasik dalam model linear yaitu linearitas, normalitas, multikolinearitas, heteroskedastisitas, dan autokorelasi. Namun, tidak semua uji asumsi klasik harus diterapkan pada model linear dalam hal ini model data panel (Gujarati, 2003)sehingga untuk data panel cukup memenuhi uji multikolinieritas dan uji heteroskedastisitas.

Uji multikolinearitas menunjukkan ada tidaknya hubungan linear antara beberapa atau semua variabel independen pada pada suatu model. Apabila terdapat multikolinearitas pada model akan meningkatkan variansi dari koefisien $\beta$ sehingga meningkat pula peluang koefisien tersebut tidak signifikan pada model. Salah satu cara untuk mendeteksi adanya multikolinearitas adalah metode VIF (Variance Inflation Factor).(Akinwande, Dikko and Samson, 2015)menyebutkan bahwa suatu variabel independen dikatakan memiliki kolinearitas tinggi dengan variabel independen lainnya apabila nilai $V I F>5$.

Uji heteroskedastisitas menunjukkan tahan tidaknya suatu model terhadap variasi galat. Heteroskedastisitas ditunjukkan dengan adanya pola tertentu dari galat terhadap nilai variabel dependen, sehingga apabila hal itu terjadi, maka model menjadi tidak efisien dan tidak stabil dalam memprediksikan suatu nilai. Pada uji ini hipotesis awal adalah tidak terdapat heteroskedastisitas pada model 
$\left(\rho_{1}=\rho_{2}=\cdots=\rho_{p}=0\right)$. Sedangkan hipotesis alternatif adalah terdapat heteroskedastisitas pada model $\left(\exists \rho_{p} \neq 0\right)$.

Pemilihan model terbaik terdapat beberapa pilihan, yang paling dasar adalah berdasarkan nilai $A d j . R^{2}, R S S$, dan $A I C$.

$\operatorname{Adj} . R^{2}$ adalah nilai $R^{2}$ yang disesuaikan dengan jumlah variabel independen pada model. Nilainya meningkat hanya apabila variabel baru meningkatkan keakuratan model lebih daripada yang diharapkan, dan menurun apabila variabel baru meningkatkan keakuratan model kurang daripada yang diharapkan. Sehingga model terbaik memiliki nilai $A d j . R^{2}$ yang lebih tinggi daripada model lainnya. $R S S$ atau jumlah kuadrat galat dari pembentukan model. Model terbaik memiliki galat yang lebih kecil daripada model lainnya.

AIC atau Akaike Information Criterion adalah penduga kesalahan prediksi relatif terhadap kualitas model statistik. Dengan adanya kumpulan model, IAC memperkirakan kualitas setiap model relatif terhadap model lainnya, sehingga AIC menyediakan sarana untuk pemilihan model. Nilai $A I C$ diperoleh dari log likelihood distribusi normal karena galat $\varepsilon_{i, t}$ memiliki rata rata nol dan variansi homogen terhadap waktu. Penelitian ini dilakukan berdasarkan pendekatan hubungan variabel. Definisi operasional dan indikator dari variabel-variabel terkait dapat dilihat pada Tabel 3.

Tabel 3.

Definisi Operasional dan Indikator Variabel

\begin{tabular}{|c|c|c|c|}
\hline No. & Variabel & Definisi Operasional & Indikator \\
\hline 1. & $\begin{array}{l}\text { Pajak Kendaraan } \\
\text { Bermotor (PPKB) }\end{array}$ & $\begin{array}{l}\text { Kontribusi wajib pajak kepada daerah yang } \\
\text { terutang oleh pribadi atau badan yang bersifat } \\
\text { memaksa }\end{array}$ & Rupiah \\
\hline 2. & $\begin{array}{l}\text { Jumlah Penduduk } \\
\text { (JP) }\end{array}$ & $\begin{array}{l}\text { Semua orang yang berdomisili di wilayah } \\
\text { geografis Kalimantan Selatan selama } 6 \text { bulan } \\
\text { atau lebih dan atau mereka yang berdomisili } \\
\text { kurang dari } 6 \text { bulan tetapi bertujuan untuk } \\
\text { menetap. }\end{array}$ & Jiwa \\
\hline 3. & $\begin{array}{l}\text { Jumlah Kendaraan } \\
\text { Bermotor }(\mathrm{JK})\end{array}$ & $\begin{array}{l}\text { Jumlah kendaraan bermotor yang terhitung } \\
\text { dalam data yang diperoleh dari Samsat }\end{array}$ & Unit \\
\hline 4. & $\begin{array}{l}\text { PDRB Perkapita } \\
\text { (PDRBP) }\end{array}$ & $\begin{array}{l}\text { Rata-rata nilai PDRB untuk masing-masing } \\
\text { penduduk di wilayah tertentu. Diperoleh dari } \\
\text { hasil pembagian antara PDRB dengan jumlah } \\
\text { penduduk pertengahan tahun. }\end{array}$ & Rupiah \\
\hline 5. & Inflasi (I) & $\begin{array}{l}\text { Kenaikan biaya variabel perunit dan harga } \\
\text { barang secara terus menerus dalam periode } \\
\text { tertentu yang dinyatakan dalam persen }\end{array}$ & Rasio \\
\hline 6. & Sistem Pajak (SP) & $\begin{array}{l}\text { Variabel kategorikal yang diduga mempunyai } \\
\text { pengaruh langsung terhadap variabel yang } \\
\text { bersifat kontinu. Dalam hal ini pengaruh } \\
\text { sistem online terhadap penerimaan pajak } \\
\text { kendaraan bermotor. }\end{array}$ & $\begin{array}{l}\text { Logit ( } 0 \text { bila } \\
\text { menggunakan } \\
\text { sistem offline dan } 1 \\
\text { bila menggunakan } \\
\text { sistem online). }\end{array}$ \\
\hline
\end{tabular}

Sumber : diolah oleh penulis (2020) 


\section{HASIL DAN PEMBAHASAN}

Peneliti menggunakan metode analisis regresi data panel dalam menganalisis faktor-faktor yang mempengaruhi penerimaan pajak kendaraan bermotor di Provinsi Kalimantan Selatan. Seluruh proses analisis data pada penelitian ini dilakukan dengan bantuan aplikasi R. Model awal yang digunakan pada data panel yaitu :

$$
y_{i, t}=x_{i, t} \beta_{i, t}+c_{i}+d_{t}+\varepsilon_{i, t}
$$

Analisis data panel meliputi beberapa proses dasar yang harus dilakukan, yaitu uji spesifikasi model, uji signifikansi model, dan uji diagnostik model serta pemilihan model terbaik apabila diperlukan. Pengujian hipotesis penelitian ini dilakukan dengan pengujian secara parsial maupun simultan dengan variabel terikat (dependent variable) yaitu penerimaan pajak kendaraan bermotor dan variabel bebas (independent variable) yaitu jumlah penduduk, jumlah kendaraan, PDRB perkapita, inflasi dan sistem pajak. Penelitian ini meliputi uji spesifikasi model diantaranya Uji Chow untuk membandingkan konsistensi antara model fixed effetct(FEM) dan modelcommon effect (CE), Uji Hausmann (Hausmann Test) untuk mengetahui random effect(REM) atau fixed effect(FEM) yang terdapat pada model. Uji spesifikasi model dilakukan pada taraf $\alpha=5 \% . H_{0}$ ditolak jika $p-$ value $<\alpha$. Hasil uji spesifikasi model dapat dilihat pada Tabel 4.

Tabel 4.

Hasil Uji Spesifikasi Model

\begin{tabular}{|c|c|c|c|}
\hline $\begin{array}{c}\text { Uji } \\
\text { Spesifikasi }\end{array}$ & Hipotesis & p-value & Kesimpulan \\
\hline Uji Chow & $\begin{array}{l}H_{0}: \text { model common effect } \text { konsisten } \\
H_{1}: \text { model fixed effect } \text { konsisten }\end{array}$ & $<2.2 \mathrm{e}-16$ & $\begin{array}{l}\text { model fixed effect } \\
\text { konsisten }\end{array}$ \\
\hline $\begin{array}{l}\text { Uji } \\
\text { Hausmann }\end{array}$ & $\begin{array}{l}H_{0}: \text { model random effect konsisten } \\
H_{1}: \text { model fixed effect konsisten }\end{array}$ & 0,01387 & $\begin{array}{l}\text { model fixed effect } \\
\text { konsisten }\end{array}$ \\
\hline
\end{tabular}

Sumber :Hasil software R (2020)

Uji spesifikasi model menunjukkan hasil bahwa model fixed effect konsisten. Hasil sebagaimana jika cross section $(\mathrm{N})$ besar dan time series $(\mathrm{T})$ kecil dan sampel cross section tidak acak maka FEM lebih direkomendasikan(Gujarati, 2003). Langkah selanjutnya setelah diketahui bahwa model fixed effect konsisten daripada model random effect, dilakukan uji Breusch-Pagan. $H_{0}$ ditolak jika $p-$ value $<\alpha$ dengan taraf signifikansi $\alpha=5 \%$. Ringkasan statistik uji tercantum pada Tabel 5.

Hasil statistik uji dari 2 uji yang dilakukan, diperoleh hasil bahwa terdapat efek individu dan efek waktu dari hipotesis pertama dan hanya terdapat efek individu dari hipotesis kedua. Berdasarkan uji spesifikasi model yang dilakukan, menunjukkan bahwa model yang akan dibentuk adalah model efek tetap (fixed effect model) dengan efek individu yang akan dibentuk. 
Tabel 5.

Ringkasan Hasil Statistik Uji Breusch-Pagan

\begin{tabular}{llcc}
\hline \multicolumn{1}{c}{ Kriteria } & \multicolumn{1}{c}{ Hipotesis } & p-value & Kesimpulan \\
\hline Efek individu dan & $H_{0}$ : Tidak terdapat efek individu dan & $<2,2 e-16$ & $H_{0}$ ditolak \\
waktu & waktu & & \\
& $H_{1}:$ Terdapat efek individu dan waktu & & \\
Efek individu & $H_{0}$ : Tidak terdapat efek individu & $<2,2 e-16$ & $H_{0}$ ditolak \\
& $H_{1}:$ Terdapat efek individu & & \\
Efek waktu & $H_{0}$ : Tidak terdapat efek waktu & 0,1279 & $H_{0}$ diterima \\
& $H_{1}$ : Terdapat efek waktu & & \\
\hline
\end{tabular}

Sumber :Hasil software R (2020)

$P K B_{i, t}=\alpha_{i}+\beta_{1}\left(J P_{i, t}\right)+\beta_{2}\left(J K_{i, t}\right)+\beta_{3}\left(P D R B P_{i, t}\right)+\beta_{4}\left(I_{i, t}\right)+\beta_{5}\left(S P_{i, t}\right)+$

$\varepsilon \ldots \ldots . .(6)$

Keterangan :

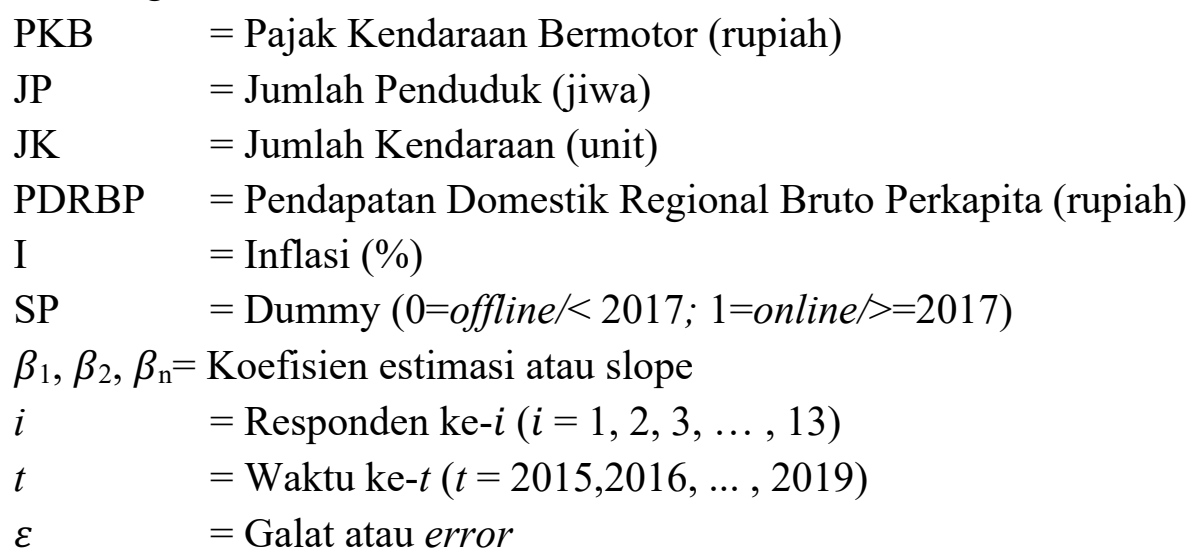

Model yang terbentuk akan diuji signifikansi variabelnya dengan taraf signifikansi $\alpha=0,05$. Hipotesis $H_{0}$ ditolak jika $p-$ value $<\alpha$. Hasil uji regresi data panel disajikan pada tabel 6 sedangkan hasil uji signifikansi koefisien model disajikan pada tabel 7 dan 8 . $H_{0}$ ditolak jika $p-$ value $<\alpha$.

Hipotesis signifikansi koefisien model (parsial)

$H_{0}$ : koefisien tidak signifikan pada model

$H_{1}$ : koefisien signifikan pada model

Hipotesis signifikansi model (simultan)

$H_{0}$ : model tanpa variabel independen dapat merepresentasikan data

$H_{l}$ : model yang dibentuk lebih baik daripada model tanpa variabel independent

Hasil uji signifikansi model pada Tabel 7 dan 8 memberi kesimpulan bahwa model memenuhi uji signifikansi model dengan hanya variabel jumlah kendaraan yang signifikan sedangkan variabel jumlah penduduk, PDRB perkapita, inflasi, dan sistem pajak tidak signifikan. Uji signifikansi model menunjukkan bahwa 
model yang dibentuk dengan variabel independen lebih baik daripada model tanpa variabel independen.

Tabel 6.

Hasil Uji Regresi Data Panel

\begin{tabular}{|c|c|c|c|c|}
\hline Variabel & Estimasi & Std. Error & t-value & Prob. \\
\hline Jumlah Penduduk & 98154,019 & 74216,207 & 1,3225 & 0,1924 \\
\hline Jumlah Kendaraan & 293203,185 & 32431,503 & 9,0407 & $7,478 \mathrm{e}-12 * * *$ \\
\hline PDRB Perkapita & 20,275 & 136,594 & 0,1517 & 0,8801 \\
\hline Inflasi & 219972126,123 & 220464684.705 & 0,9978 & 0,3235 \\
\hline Siste.Pajak & 362704704,693 & 677565343,886 & 0,5353 & 0,5950 \\
\hline \multicolumn{5}{|l|}{ Fixed Effects (Cross) } \\
\hline Balangan & -16916383115 & Kota Banjarmasin & & -101168355866 \\
\hline Banjar & -44873908733 & Kotabaru & & -44944598400 \\
\hline Barito Kuala & -35782977012 & Tabalong & & -29106367289 \\
\hline Hulu Sungai Selatan & -31318337503 & Tanah Bumbu & & -41068995549 \\
\hline Hulu Sungai Tengah & -38060166699 & Tanah Laut & & -44860831984 \\
\hline Hulu Sungai Utara & -30058493408 & Tapin & & -26653148236 \\
\hline Kota Banjarbaru & -15511081780 & & & \\
\hline \multicolumn{5}{|l|}{ Effects Specification } \\
\hline$R$-Squared & \multicolumn{2}{|c|}{0,95881} & & \\
\hline Adj. R-Squared & \multicolumn{2}{|c|}{0,94391} & & \\
\hline Total Sum of Squares & \multicolumn{2}{|c|}{$2,1284 \mathrm{e}+21$} & & \\
\hline Residual Sum of Squares & \multicolumn{2}{|c|}{$8,7668 \mathrm{e}+19$} & & \\
\hline$F$-statistic & \multicolumn{2}{|c|}{218,811} & & \\
\hline $\operatorname{Prob}(F$-statistic $)$ & \multicolumn{2}{|c|}{$<2,22 \mathrm{e}-16$} & & \\
\hline
\end{tabular}

Sumber : Hasil software R (2020)

Tabel 7.

Hasil Statistik Uji Signifikansi Koefisien Model

\begin{tabular}{lccc}
\hline \multicolumn{1}{c}{ Koefisien } & $\boldsymbol{p}$-value & Kriteria & Kesimpulan \\
\hline Jumlah Penduduk & 0,44493 & $H_{0}$ diterima & Koefisien tidak signifikan \\
Jumlah Kendaraan & $1,1991 \cdot 10^{-6}$ & $H_{0}$ ditolak & Koefisien signifikan \\
PDRB Perkapita & 0,51944 & $H_{0}$ diterima & Koefisien tidak signifikan \\
Inflasi & 0,04698 & $H_{0}$ diterima & Koefisien tidak signifikan \\
Sistem.Pajak & 0,12603 & $H_{0}$ diterima & Koefisien tidak signifikan \\
\hline
\end{tabular}

Sumber :Hasil software R (2020)

Tabel 8.

Hipotesis Signifikansi Model

\begin{tabular}{|c|c|c|}
\hline$p-$ value & Kriteria & Kesimpulan \\
\hline $\begin{array}{l}<2,22 \\
\cdot 10^{-16}\end{array}$ & $H_{0}$ ditolak & $\begin{array}{l}\text { Model yang dibentuk lebih baik daripada model tanpa } \\
\text { variabel independen }\end{array}$ \\
\hline
\end{tabular}

Sumber :Hasil software R (2020) 
Uji selanjutnya yang dilakukan adalah uji diagnostik. Terdapat dua uji diagnostik yang dilakukan yaitu uji multikolinieritas (korelasi serial) dan uji heteroskedastis. Uji multikolinieritas bertujuan untuk mengetahui ada tidaknya korelasi serial komponen error pada model, sedangkan uji heteroskedastis bertujuan untuk mengetahui tahan (robust) tidaknya model terhadap variansi error. Model yang baik berdasarkan uji diagnostik adalah yang tidak ada korelasi serial dan tahan terhadap variansi error (tidak heteroskedastis atau homoskedastis). Hasil statistik uji multikolinieritas dan kesimpulan tercantum pada Tabel 9.

Tabel 9.

Hasil Statistik Uji Multikolinieritas

\begin{tabular}{lcl}
\hline \multicolumn{1}{c}{ Variabel } & VIF & \multicolumn{1}{c}{ Kesimpulan } \\
\hline Jumlah Penduduk & 3,381619 & Tidak terdapat multikolinieritas \\
Jumlah Kendaraan & 3,243817 & Tidak terdapat multikolinieritas \\
PDRB Perkapita & 1,148262 & Tidak terdapat multikolinieritas \\
Inflasi & 1,354118 & Tidak terdapat multikolinieritas \\
Sistem Pajak & 1,354365 & Tidak terdapat multikolinieritas \\
\hline
\end{tabular}

Sumber :Hasil software R (2020)

Hasil uji multikolinieritas terhadap 5 (lima) variabel independen menunjukkan bahwa diperoleh nilai Variance Inflation Factor (VIF) masingmasing variabel kurang dari 5, Akinwande menyebutkan bahwa suatu variabel independen dikatakan memiliki kolinearitas tinggi dengan variabel independen lainnya apabila nilai $V I F>5$ sehingga dapat disimpulkan bahwa tidak terdapat multikolinieritas pada variabel independen (Akinwande, Dikko and Samson, 2015). Uji diagnostik yang kedua adalah uji heteroskedastis dengan taraf signifikansi $\alpha=0,05$ dengan hipotesis

$H_{0}$ : tidak terdapat heteroskedastisas

$H_{1}$ :terdapat heteroskedastisas

$H_{0}$ ditolak jika $p$-value $<\alpha$. Hasil statistik uji dan kesimpulan pada uji heteroskedastis tercantum pada Tabel 10.

Tabel 10.

Hasil Statistik Uji Heteroskedastis

p-value $\quad$ Kriteria $\quad$ Kesimpulan


$H_{0}$ ditolak Tidak terdapat heteroskedastisitas

0,7808

Sumber :Hasil software R (2020)

Uji diagnostik memberikan hasil bahwa model yang dibentuk tidak terdapat heteroskedastisitas sehingga lolos uji diagnostik. Berikut model fixed effect dengan efek individu beserta variabel independennya yang dapat dituliskan ke dalam model,

Keterangan :

$$
\begin{aligned}
P K B_{i, t}=\alpha_{i}+ & 98154,01851\left(J P_{i, t}\right)+293203,18478\left(J K_{i, t}\right) \\
& +20,72508\left(P D R B P_{i, t}\right)+219972126,12298\left(I_{i, t}\right) \\
& +362704704\left(S P_{i, t}\right)+\varepsilon
\end{aligned}
$$

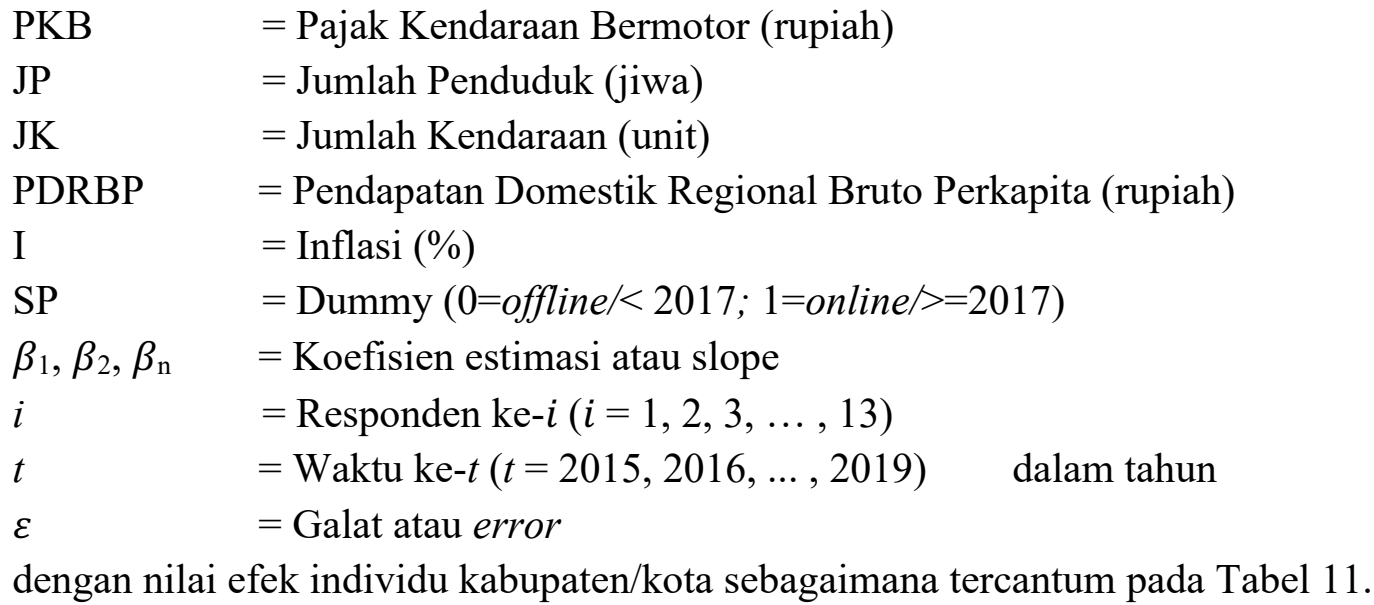

Tabel 11.

Hasil Statistik Uji Heteroskedastis

\begin{tabular}{lc}
\hline \multicolumn{1}{c}{ Kabupaten/Kota } & Efek Individu \\
\hline Balangan & -16916382618 \\
Banjar & -44873908890 \\
Barito Kuala & -35782977002 \\
Hulu Sungai Selatan & -31318337471 \\
Hulu Sungai Tengah & -38060166698 \\
Hulu Sungai Utara & -30058493423 \\
Kota Banjarbaru & -15511081773 \\
Kota Banjarmasin & -101168356340 \\
Kotabaru & -44944598134 \\
Tabalong & -29106366999 \\
Tanah Bumbu & -41068995404 \\
Tanah Laut & -44860831937 \\
Tapin & -26653148083 \\
\hline
\end{tabular}

Sumber :Hasil software R (2020) 
Hasil estimasi uji regresi data panel menunjukkan bahwa nilai intersep untuk setiap kabupaten/kota di Provinsi Kalimantan Selatan berbeda. Keadaan ini mengindikasikan bahwa terdapat perbedaan pada besaran penerimaan pajak kendaraan bermotor dari setiap kabupaten/kota di Provinsi Kalimantan Selatan. Bila dilihat dari nilai koefisien variabel, terlihat bahwa setiap kabupaten/kota di Provinsi Kalimantan Selatan memiliki nilai koefisien yang sama. Hal ini mengindikasikan pula bahwa perilaku antar kabupaten/kota di Provinsi Kalimantan Selatan diasumsikan adalah sama. Berdasarkan hasil uji regresi data panel, didapat model dengan memasukkan koefisien estimasi sehingga model menjadi,

$$
\begin{aligned}
P K B_{i, t}=\alpha_{i} & +98154,019\left(J P_{i, t}\right)+293203,185\left(J K_{i, t}\right)+20,725\left(P D R B P_{i, t}\right) \\
& +219972126,123\left(I_{i, t}\right)+362704704,693\left(S P_{i, t}\right)+\varepsilon
\end{aligned}
$$

\begin{tabular}{|c|c|}
\hline PKB & $=$ Pajak Kendaraan Bermotor (rupiah) \\
\hline $\mathrm{JP}$ & $=$ Jumlah Penduduk (jiwa) \\
\hline $\mathrm{JK}$ & $=$ Jumlah Kendaraan (unit) \\
\hline PDRBP & $=$ Pendapatan Domestik Regional Bruto Perkapita (rupiah) \\
\hline I & $=$ Inflasi $(\%)$ \\
\hline SP & $=$ Dummy $(0=$ offline $/<2017 ; 1=$ online $>=2017)$ \\
\hline$\beta_{1}, \beta_{2}, \beta_{\mathrm{n}}$ & $=$ Koefisien estimasi atau slope \\
\hline$i$ & $=$ Responden ke- $i(i=1,2,3, \ldots, 13)$ \\
\hline$t$ & $=$ Waktu ke- $t(t=2015,2016, \ldots, 2019)$ dalam tahun \\
\hline$\varepsilon$ & $=$ Galat atau error \\
\hline
\end{tabular}

Keterangan :

Hasil analisis regresi data panel juga menunjukkan bahwa dalam pengaruh secara simultan antara jumlah penduduk, jumlah kendaraan, PDRB perkapita, inflasi dan sistem pajak terhadap penerimaan $\mathrm{PKB}$ ditentukan dengan tingkat signifikan 5\% $(0,05)$ dan derajat kebebasan $\mathrm{df}_{1}=5 \mathrm{dan}_{\mathrm{df}_{2}}=47$ maka didapat $\mathrm{F}_{\text {tabel }}$ $(5,47)=2,4128$. $H_{0}$ ditolak jika $\mathrm{p}$-value $<\alpha$. Hipotesis yang digunakan adalah,

$\mathrm{H}_{0}$ : model tanpa variabel bebas dapat menjelaskan data

$\mathrm{H}_{1}$ : model yang dibentuk dengan variabel bebas lebih baik daripada model tanpa variabel bebas

Hasil pengujian secara simultan diperoleh nilai $\mathrm{F}_{\text {hitung }}$ sebesar 218,811 dan signifikansi $<2$,22e-16 yang berarti menunjukkan nilai $F_{\text {hitung }}>F_{\text {tabel }}$ yaitu $218,811>2,4128$ dengan signifikansi $<2,22 \mathrm{e}-16<0,05$ maka $\mathrm{H}_{0}$ ditolak dan $\mathrm{H}_{1}$ diterima. Hasil ini memberikan kesimpulan bahwa variabel jumlah penduduk, jumlah kendaraan, PDRB perkapita, inflasi dan sistem pajak secara simultan berpengaruh terhadap penerimaan pajak kendaraan bermotordi Provinsi Kalimantan Selatan. Model yang dibentuk dengan variabel bebas (jumlah penduduk, jumlah kendaraan, PDRB perkapita, inflasi, dan sistem pajak) lebih baik daripada model tanpa variabel bebas.Kemudiandilihat nilai $R$-Squared model 
sebesar 0,95881 menunjukkan bahwa 95,88\% penerimaan pajak kendaraan bermotor di Provinsi Kalimantan Selatan dijelaskan oleh variabel jumlah penduduk, jumlah kendaraan, PDRB perkapita, inflasi dan sistem pajak, sedangkan sisanya yaitu 4,12 persen dijelaskan oleh variabel lain di luar penelitian ini. Koefisien model regresi menunjukkan bahwa, untuk setiap kenaikan 1 satuan jumlah penduduk akan meningkatkan penerimaan pajak kendaraan bermotor sebesar Rp 98.154,019,--, untuk setiap kenaikan 1 satuan jumlah kendaraan akan meningkatkan penerimaan pajak kendaraan bermotor sebesar Rp 293.203,185,-, untuk setiap kenaikan 1 satuan PDRB Perkapita akan meningkatkan penerimaan pajak kendaraan bermotor sebesar Rp 20,725,-, untuk setiap kenaikan 1 satuan inflasi akan meningkatkan penerimaan pajak kendaraan bermotor sebesar Rp 219.972.126,123,-, untuk sistem pajak online akan meningkatkan penerimaan pajak kendaraan bermotor sebesar Rp 362.704.704,693,- dibandingkan sistem pajak offline.

Hasil pengujian secara parsial menunjukkan bahwa hanya variabel jumlah kendaraan yang berpengaruh terhadap penerimaan pajak kendaraan bermotor di Provinsi Kalimantan Selatan dengan $t_{\text {hitung }}(9,0407)>t_{t a b e l}(2,0117)$ dengan signifikansi 7.478e-12<0,05. Disimpulkan bahwa bahwa $\mathrm{H}_{0}$ ditolak dan $\mathrm{H}_{1}$ diterima, dengan demikian secara parsial jumlah kendaraan berpengaruh terhadap penerimaan pajak kendaraan bermotor. Hasil analisis regresi data panel menunjukkan bahwa variabel jumlah kendaraan memberikan tanda positif dan secara statistik signifikan mempengaruhi penerimaan pajak kendaraan bermotor di Provinsi Kalimantan Selatan. Hal ini menunjukkan bahwa semakin banyak jumlah kendaraan bermotor maka penerimaan pajak kendaraan bermotor juga akanmengalami peningkatan. Disebabkan karena jumlah kendaraan bermotor merupakan determinasi besaran potensi pajak kendaraan bermotor.

Penelitian ini sejalan dengan hasil penelitian yang dilakukan oleh Saputra yang menunjukkan bahwa jumlah kendaraan berpengaruh positif terhadap penerimaan pajak kendaraan bermotor di Kota Yogyakarta. Semakin banyak jumlah kendaraan bermotor dan meningkatnya kesadaran wajib pajak untuk membayar pajak kendaraan bermotor serta semakin baiknya pengelolaan pemungutan pajak kendaraan bermotor yang dilakukan secara terpadu melalui Samsat juga akan meningkatkan penerimaan pajak kendaraan bermotor (Saputra, 2018). Secara parsial terdapat pengaruh yang signifikan antara jumlah kendaraan dengan penerimaan pajak kendaraan bermotor di Provinsi Kalimantan Selatan tahun 2015-2019. Hal ini menunjukkan bahwa semakin banyak jumlah kendaraan bermotor maka penerimaan pajak kendaraan bermotor juga akan mengalami peningkatan. Disebabkan karena jumlah kendaraan bermotor merupakan determinasi besaran potensi pajak kendaraan bermotor. Adapun perhitungan potensi pajak merupakan hasil kali antara pajak terutang dikali dengan jumlah kendaraan masing-masing jenis kendaraan. Pajak terutang sendiri merupakan hasil kali antara tarif pajak dengan dasar pengenaan pajak. Dan yang menjadi dasar pengenaan pajak adalah Nilai Jual Kendaraan Bermotor (NJKB) dikalikan dengan bobot. Sehingga semakin besar jumlah kendaraan bermotor yang menjadi obyek pajak maka semakin besar penerimaan pajak kendaraan bermotor. Sebagaimana 
yang dikemukakan oleh Prakoso bahwa dalam pemungutan pajak, jumlah subjek dan objek akan mempengaruhi penerimaan pajak dari hasil pungutan tersebut (Prakoso, 2005).

Hasil wawancara dengan Kasubbid Pajak Badan Keuangan Daerah Provinsi Kalimantan Selatan menjelaskan bahwa semakin banyak jumlah kendaraan bermotor yang ada di Kalimantan Selatan maka semakin besar penerimaan pajak kendaraan bermotor yang bisa didapatkan karena jumlah kendaraan bermotor menunjukkan jumlah obyek pajak kendaraan yang dapat dipungut oleh Pemerintah Provinsi Kalimantan Selatan. Besarnya jumlah kendaraan bermotor yang ada selama ini menjadi peluang bagi Pemerintah Provinsi Kalimantan Selatan untuk meningkatkan penerimaan dari sektor pajak kendaraan bermotor. Baik kendaraan bermotor yang ada di wilayah Kalimantan Selatan maupun yang berada di luar wilayah Kalimantan Selatan tetap diperhitungkan ke dalam penerimaan pajak kendaraan bermotor di Kalimantan Selatan asalkan kendaraan tersebut terdaftar di wilayah Kalimantan Selatan. Jumlah kendaraan bermotor di Kalimantan Selatan selama ini selalu mengalami peningkatan dari tahun ke tahun, baik yang berasal dari Bea Balik Nama (BBN) 1 ataupun dari BBN 2 yaitu kendaraan yang berasal dari adanya kegiatan transaksional secara hukum misalnya dari kegiatan jual beli sehingga terjadi pemindahtanganan atau perubahan status kepemilikan.

Hasil pengujian secara parsial terhadap variabel jumlah penduduk menunjukkan $t_{\text {hitung }}(1,3225)<t_{\text {tabel }}(2,0117)$ dengan signifikansi $0,1924>0,05$. Disimpulkan bahwa $\mathrm{H}_{0}$ diterima, dengan demikian secara parsial jumlah penduduk berpengaruh terhadap penerimaan pajak kendaraan bermotor. Hal ini disebabkan tidak semua jumlah penduduk yang ada di Provinsi Kalimantan Selatan merupakan wajib pajak kendaraan bermotor. Terdapat lebih dari $50 \%$ jumlah penduduk Kalimantan Selatan yang termasuk ke dalam usia belum dan tidak produktif ataupun penduduk yang tidak berpenghasilan tetap, sehingga jumlah penduduk yang besar tidak menjadi jaminan besarnya wajib pajak. Hasil penelitian ini sejalan dengan penelitian yang dilakukan oleh Sari menunjukkan bahwa jumlah penduduk tidak berpengaruh positif terhadap pajak daerah (Sari, 2016). Hal ini berarti semakin tinggi jumlah penduduk, belum tentu akan meningkatkan penerimaan pajak daerah, namun penelitian ini tidak sejalan dengan teori perpajakan menurut Musgrave yang menyatakan bahwa besar kecilnya penerimaan di sektor pajak sangat ditentukan oleh jumlah penduduk, sehingga dapat dikatakan jumlah penduduk berpengaruh terhadap banyaknya jumlah penyetor pajak daerah berdasarkan pendapatan yang diperoleh masing-masing penyetor untuk membayar pajak daerah tersebut (Musgrave, 1989). Pertambahan jumlah penduduk dianggap akan menciptakan atau meningkatkan permintaan agregatif terutama investasi maupun jumlah penyetor pajak daerah tersebut dan tidak sejalan dengan penelitian yang dilakukan oleh Sania et al. yang menunjukkan bahwa variabel jumlah penduduk berpengaruh signifikan terhadap penerimaan pajak daerah. Hal ini disebabkan karena syarat dalam pemungutan pajak diantaranya harus adanya subyek pajak, maka dengan meningkatnya jumlah penduduk, akan semakin bertambah jumlah penduduk yang menikmati jasa 
pelayanan yang diberikan oleh pemerintah daerah yang bersumber dari pajak daerah (Sania. H, Yunita. A, 2018).

Hasil pengujian secara parsial terhadap variabel PDRB perkapita menunjukkan $t_{\text {hitung }}(0,1517)<t_{\text {tabel }}(2,0117)$ dengan signifikansi $0,8801>$ 0,05.Disimpulkan bahwa $\mathrm{H}_{0}$ diterima, dengan demikian secara parsial PDRB perkapita tidak berpengaruh terhadap penerimaan pajak kendaraan bermotor. Hal ini disebabkan PDRB perkapita masyarakat yang tinggi bukan menjadi kewajiban ataupun indikator masyarakat untuk memiliki kendaraan bermotor, bisa saja jumlah kepemilikan kendaran masyarakat disesuaikan pada tingkat kebutuhan, bukan pada tingkat pendapatan. Hasil penelitian ini sejalan dengan penelitian Nyalung bahwa pendapatan tidak berpengaruh terhadap penerimaan pajak kendaraan bermotor di SAMSAT Palangka Raya (Nyalung and Djalil, 2020), namun hasil penelitian ini bertentangan dengan hasil penelitian yang dilakukan oleh Sari menunjukkan bahwa pendapatan perkapita (NPDRB) berpengaruh terhadap penerimaan pajak daerah, disebabkan PDRB sangat erat kaitannya dengan pajak daerah karena dapat menggambarkan pertumbuhan ekonomi suatu daerah (Sari, 2016).

Hasil pengujian secara parsial terhadap variabel inflasi menunjukkan $t_{\text {hitung }}(0,9978)<t_{\text {tabel }}(2,0117)$ dengan signifikansi $0,3235>0$,05.Disimpulkan bahwa bahwa $\mathrm{H}_{0}$ diterima, dengan demikian secara parsial inflasi tidak berpengaruh terhadap penerimaan PKB. Hal ini disebabkan karena membayar pajak kendaraan bermotor adalah kewajiban bagi setiap wajib pajak terdaftar yang memiliki hal atau penguasaan terhadap kendaraan bermotor, sehingga berapapun kenaikan ataupun penurunan tingkat inflasi tidak mengurangi kewajiban masyarakat untuk membayar pajak. Hasil penelitian ini sejalan dengan penelitian Sania et al. yang menunjukkan bahwa variabel inflasi tidak berpengaruh secara signifikan terhadap penerimaan pajak daerah (Sania. H, Yunita. A, 2018). Hal ini berarti ketika inflasi naik secara terus menerus, masyarakat akan tetap membayar pajak daerah dikarenakan pajak dapat bersifat memaksa, namun hasil penelitian ini bertentangan dengan penelitian yang dilakukan oleh Lumy et al. yang menyebutkan bahwa inflasi berpengaruh positif dan signifikan terhadap penerimaan pajak daerah (Lumy, Kindangen and Engka, 2019). Apabila inflasi meningkat penerimaan pajak daerah juga akan meningkat begitu pula sebaliknya ceteris paribus. Hal ini diduga karena inflasi menyebabkan naiknya harga barang dan jasa yang berimbas pada tingginya Nilai Jual Kendaraan Bermotor sehingga dasar pengenaan pajak juga semakin besar.

Hasil wawancara dengan Kepala Sub Bidang Analisa dan Inovasi Pendapatan Badan Keuangan Daerah Provinsi Kalimantan Selatan menjelaskan bahwa pajak kendaraan bermotor merupakan kewajiban yang harus dibayar oleh seluruh wajib pajak yang terdaftar. Sehingga perubahan kondisi ekonomi makro dalam hal ini inflasi tidak begitu mempengaruhi penerimaan pajak kendaraan bermotor dari sisi kepatuhan wajib pajak. Meskipun terjadi perubahan harga secara terus-menerus pada seluruh kebutuhan masyarakat, masyarakat tetap harus membayar pajak sesuai dengan besaran yang telah ditentukan berdasarkan hasil perhitungan dasar pengenaan pajak kendaraan bermotor yang terutang. Bagi wajib pajak yang tidak memenuhi kewajibannya tetap akan dikenakan sanksi 
administrasi berupa denda sesuai dengan ketentuan yang berlaku. Penghapusan denda pajak dapat diberlakukan jika pemerintah daerah memberikan kebijakankebijakan khusus dalam rangka menstimulus penerimaan pajak kendaraan bermotor di Provinsi Kalimantan Selatan. Pengaruh positif inflasi terhadap penerimaan pajak kendaraan bermotor disini lebih kepada perubahan NJKB yang menjadi dasar pengenaan pajak.

Hasil pengujian secara parsial terhadap variabel sistem pajak menunjukkan $t_{\text {hitung }}(0,5353)<t_{\text {tabel }}(2,0117)$ dengan signifikansi $0,5950>0,05$. Disimpulkan bahwa bahwa $\mathrm{H}_{0}$ diterima, dengan demikian secara parsialsistem pajak online tidak berpengaruh terhadap penerimaan pajak kendaraan bermotor. Hal ini dikarenakan wajib pajak akan tetap membayar pajak sesuai dengan kewajibannya walaupun dilakukan pemungutan dengan menggunakan sistem offline ataupun sistem online. Hasil penelitian ini sejalan dengan penelitian yang dilakukan oleh Polohoonet al. menunjukkan bahwa pelayanan pembayaran online tidak berpengaruh terhadap penerimaan pajak kendaraan bermotor di Provinsi Sulawesi Utara (Polohoon, Rumate and Engka, 2019). Penelitian ini bertentangan dengan yang dilakukan oleh Mesoino bahwa terdapat pengaruh yang signifikan pada jumlah penerimaan pajak kendaraan bermotor sebelum dan sesudah penerapan $e$ samsat atau dengan kata lain terdapat perbedaan penerimaan pajak kendaraan bermotor sebelum dan sesudah penerapan e-samsat (Mesoino, 2020).

Sistem administrasi perpajakan yang diterapkan pada dasarnya mampu menentukan minat masyarakat dalam membayar pajak. Sebagaimana yang dikemukakan bahwa administrasi perpajakan merupakan salah satu unsur dari sistem perpajakan yang sangat menentukan keberhasilan dalam pemungutan pajak, karena tanpa adanya administrasi perpajakan yang efektif sangat sulit bagi lembaga/organisasi pemungut pajak untuk melaksanakan kebijakan perpajakan. Pengalaman di berbagai negara, resep dasar untuk mewujudkan administrasi perpajakan yang efektif hanya memiliki tiga komponen, yaitu 1) kemauan politik untuk mengelola sistem pajak secara efektif, 2) strategi yang jelas untuk mencapai tujuan ini, dan 3) sumber daya yang memadai untuk tugas tersebut (Bird, 2008). Administrasi perpajakan yang kurang baik bisa menyebabkan proses pemungutan pajak menjadi lambat, berbelit-belit dan menghabiskan waktu yang lama. Hingga pada akhirnya mengurangi minat masyarakat selaku wajib pajak untuk berpartisipasi secara aktif dalam proses pemungutan pajak kendaraan bermotor. Mekanisme dan prosedur pembayaran pajak yang masih rumit dapat mempengaruhi kepatuhan masyarakat dalam membayar pajak. Masyarakat cenderung akan menunda-nunda pembayaran pajak kendaraan mereka bahkan tak sedikit yang justru tidak membayarnya, sehingga menyebabkan piutang pajak meningkat.

Pemerintah Provinsi Kalimantan Selatan memiliki tugas dan tanggung jawab untuk memberikan pelayanan yang terbaik bagi para wajib pajak kendaraan bermotor, sehingga dilakukan inovasi kebijakan berupa penerapan sistem pembayaran pajak secara online melalui $e$-samsat yang efektif dilaksanakan sejak triwulan pertama tahun 2017. Kebijakan ini terus dikembangkan hingga pada tahun 2019 Pemerintah Provinsi Kalimantan Selatan juga menerapkan kebijakan pembayaran pajak kendaraan bermotor melalui Samsat Online Nasional 
(Samolnas). Kebijakan ini juga sejalan dengan penelitian yang dilakukan oleh Mesoino mengenai penerapan $e$-samsat dalam pembayaran pajak kendaraan bermotor. Dalam penelitiannya yang menunjukkan bahwa salah satu alasan mengapa terjadi peningkatan penerimaan pajak kendaraan bermotor dan juga terdapat perbedaan penerimaan pajak kendaraan bermotor ini dikarenakan fasilitas yang diberikan pemerintah daerah berupa sistem pembayaran pajak kendaraan bermotor online berbasis $e$-samsat merupakan sarana mempermudah pembayaran pajak kendaraan bermotor dan sebagai strategi yang fokus pada kepuasan pelayanan wajib pajak (Mesoino, 2020).

Hasil wawancara yang dilakukan dengan Kepala Bidang Pajak Daerah bahwa sejak diterapkan sistem pembayaran secara online baik $e$-samsat maupun samolnas, realisasi penerimaan pajak kendaraan bermotor semakin meningkat. Hal ini terlihat dari peningkatan jumlah transaksi pembayaran melalui aplikasi $e$ samsat maupun via teller bank sejak pertama kali sistem ini diterapkan hingga akhir tahun 2020, namun penggunaan sistem online masih belum sebanding dengan sistem pembayaran yang dilakukan secara offline. Kewajiban membayar pajak kendaraan bermotor sejatinya tetap harus dipenuhi terlepas dari sistem pembayaran apa yang digunakan, sehingga sistem pembayaran pajak yang berlaku saat ini hanya sebagai katalisator bukan sebagai determinan besaran pajak kendaraan bermotor yang diterima.

\section{SIMPULAN}

Faktor yang mempengaruhi penerimaan pajak kendaraan bermotor di Provinsi Kalimantan Selatan tahun 2015-2019 adalah jumlah kendaraan. Hasil penelitian ini berimplikasi bahwa dalam meningkatkan penerimaan pajak kendaraan bermotor, Pemerintah Provinsi Kalimantan Selatan dapat melakukan beberapa upaya diantaranya adalah meningkatkan jumlah subyek dan obyek pajak kendaraan bermotor serta melakukan inovasi terhadap sistem pelayanan perpajakan kendaraan bermotor. Hal ini disebabkan adanya indikasi bahwa sistem pelayanan perpajakan kendaraan bermotor mempengaruhi penerimaan pajak kendaraan bermotor melalui peningkatan jumlah pajak kendaraan bermotor yang dibayarkan.

Penelitian ini hanya menganalisis permasalahan berdasarkan data sekunder lima tahun terakhir namun belum menganalisis faktor-faktor yang mempengaruhi penerimaan pajak kendaraan bermotor berdasar persepsi masyarakat selaku wajib pajak kendaraan bermotor sehingga disarankan pada penelitian selanjutnya akan lebih baik jika menggunakan data pada kurun waktu yang lebih lama dan menggunakan persepsi masyarakat dalam menganalisis faktor-faktor yang mempengaruhi penerimaan pajak kendaraan bermotor misalnya kepatuhan wajib pajak, pengetahuan wajib pajak, kualitas pelayanan dan akses pajak.

\section{REFERENSI}

Akinwande, M. O., Dikko, H. G. and Samson, A. (2015) 'Variance Inflation Factor: As a Condition for the Inclusion of Suppressor Variable(s) in 
Regression Analysis', Open Journal of Statistics. doi: 10.4236/ojs.2015.57075.

Badan Perencanaan dan Pembangunan Daerah, P. K. S. (2019) Rencana Kerja Pemerintah Daerah Tahun 2020. Banjarbaru.

Badan Pusat Statistik, P. K. S. (2019) Statistik Keuangan Pemerintahan Provinsi 2016-2019. Banjarbaru.

Bird, R. M. (2008) The BLLR Approach to Tax Reform in Emerging Countries. United States: Georgia State University.

Gujarati, D. N. (2003) Basic Econometrics 4th Edition. New York: McGraw-Hill.

Lumy, D. G., Kindangen, P. and Engka, D. S. M. (2019) 'ANALISIS FAKTORFAKTOR YANG MEMPENGARUHI PENERIMAAN PAJAK DAERAH PADA PEMERINTAH PROVINSI SULAWESI UTARA', JURNAL PEMBANGUNAN EKONOMI DAN KEUANGAN DAERAH. doi: 10.35794/jpekd.19771.19.6.2018.

Mesoino, G. C. (2020) 'Analisis Penerimaan Pajak Kendaraan Bermotor Sebelum dan Sesudah Penerapan Sistem Pembayaran Pajak Online Berbasis ESamsat di Provinsi Sulawesi Utara', Jurnal Berkala Ilmiah Efisiensi, 20(02), pp. 130-141.

Musgrave, R. A. P. (1989) Keuangan Negara dalam Teori dan Praktek. Jakarta: Erlangga.

Nyalung, Y. I. and Djalil, A. (2020) 'Pengaruh Kepatuhan Wajib Pajak, Efektifitas Sistem, Perpajakan dan Pendapatan Terhadap Penerimaan Pajak Kendaraan Bermotor (Studi Kasus Di Kota Palangka ...', Edunomics Journal.

Polohoon, I. W., Rumate, V. A. and Engka, D. S. M. (2019) 'PENGARUH PELAYANAN SISTEM PEMBAYARAN ONLINE TERHADAP PENERIMAAN PAJAK KENDARAAN BERMOTOR (STUDI PADA BADAN PENDAPATAN DAERAH PROVINSI SULAWESI UTARA)', JURNAL PEMBANGUNAN EKONOMI DAN KEUANGAN DAERAH. doi: 10.35794/jpekd.27976.19.10.2019.

Prakoso, K. B. (2005) Pajak dan Retribusi Daerah. Yogyakarta: UII Press.

Sania. H, Yunita. A, M. I. (2018) 'Pengaruh Jumlah Penduduk, Produk Domestik Regional Bruto dan Inflasi terhadap Penerimaan Pajak Bumi dan Bangunan pada Kabupaten dan Kota di Provinsi Jawa Tengah', Jurnal Permana. 
Dwi Ajeng Kartini Apriliyanti, Analisis Faktor-Faktor...

Saputra, M. (2018) 'PENGARUH JUMLAH DAN MUTASI KENDARAAN BERMOTOR TERHADAP PENERIMAAN PAJAK KENDARAAN BERMOTOR DI KOTA YOGYAKARTA', Jurnal Ekobis Dewantara.

Sari, D. P. (2016) 'Analisis Faktor-faktor yang Mempengaruhi Penerimaan Pajak Daerah di Provinsi Bengkulu', Jurnal Akuntansi, 6(1), pp. 75-84. 